\title{
Evaluation of Digestibility and Nutritive Potentials of Citrus sinensis and Musa paradisiaca biologically treated with Three White Rot Fungi
}

\author{
Nwafor, S.O and Adenipekun, C.O \\ Department of Botany, Faculty of Science, University of Ibadan, Oyo State, Nigeria. \\ Corresponding author: Adenipekun, C .O. : oyinpek@yahoo.com +234-8055265186 \\ Original submitted in on $9^{\text {th }}$ April 2018. Published online at www.m.elewa.org on $31^{\text {st }}$ August 2018 \\ https://doi.org/10.35759/JABs.128.3
}

\begin{abstract}
Objective To investigate the digestibility and nutritive quality of sweet orange and ripe plantain peels treated with the spawns of Lentinus squarrosulus, Pleurotus pulmonarius and Pleurotus ostreatus (HK35) incubated for 0,30 and 60 days.

Methodology and Results: $25 \mathrm{~g}$ of each milled substrates were weighed into thoroughly washed jam bottles and 70ml-distilled water was added. The bottle was immediately covered with aluminium foil, fresh weights of the bottles determined and the bottles were sterilized in the autoclave at $121^{\circ} \mathrm{C}$ for $15 \mathrm{~min}$. The substrate bottles were left to cool and each was inoculated with $5 \mathrm{~g}$ of pure mushroom spawn at the centre and incubated at $28 \pm 2^{\circ} \mathrm{C}$ for 30 and 60 days incubation periods while the control ( 0 days) was left un-inoculated. The samples were prepared in triplicates. The dry matter, lignin, cellulose, hemicellulose, $\mathrm{pH}$, digestibility and organic matter content were determined using standard techniques. The lowest lignin level of 54.86\% was observed in peels treated with P. ostreatus after 30 days incubation period while $19.20 \%$ and $8.60 \%$ were the lowest cellulose and hemicelluloses levels recorded for peels treated with L. squarrosulus after 60days and 30 days respectively. The $\mathrm{pH}$ level increased as the incubation period increased with the highest increment of 6.82 recorded for plantain peels treated P.pulmonarius and the lowest organic matter content of $8.79 \%$ observed in plantain peels treated with $L$. squarrosulus. The dry matter content increased as the incubation period increased. The greatest digestibility $(26.50 \%)$ was observed in plantain peels treated with L.squarrosulus.

Conclusion and Applications of Results: The ability of the fungi to improve these components of the peels varied among the species as increased digestibility, reduced lignin and $\mathrm{pH}$ contents were recorded. Hence, making these wastes better sources of feed for ruminants' production.
\end{abstract}

Keywords: Biological treatment, Pleurotus ostreatus, P. pulmonarius, Lentinus squarrosulus, Plantain peels, Orange peels.

\section{INTRODUCTION}

The world food economy is gradually moving towards livestock production, and to sustain this growing economy, it is pertinent to discover and utilize alternative feed resources particularly those not competing with human (FAO, 2013). Livestock productions in the tropics are faced with the problems of low quality feeds (Babayemi et al.,
2004). Agro-wastes products are unconventional resources generated in tonnes all over the world which can be utilized for ruminants production, although, the poor nutritive quality and presence of recalcitrant fibres such as lignin reduces its digestion in the rumen of ruminants (Jonathan et al., 2010; Adenipekun and Dada; 2013). Pala et al. 
(2014) reported that over $70 \%$ of agro-industrial products are discarded as waste. Various treatments such as physical, chemical and biological techniques have been documented to be effective in enhancing the nutritive quality and digestibility of these wastes. Biological treatments such as the use of white rot fungi have been reported by various authors to be less toxic and environmentally friendly in converting agrowastes products into value added products such as feed (Akinfemi et al, 2012; Adenipekun et al., 2012). Ripe Plantain peels and sweet orange peels are easily accessible agro wastes products. Akinsanmi et al. (2015) reported than plantain could be used as nutraceuticals in animal health due to the presence of phytochemicals such as saponins, tannins, flavonoid, steroids and terpenoids. However, Akinyele and Agbro (2007) pointed out that the nutritional value of plantain waste can be increased by fermentation technology. Wanderley et al (1994) reported that citrus peels could be used as an energy giving feedstuff replacing cereal grain or silage in diet for cattle. Oloche et al (2013) reported that incorporation of sweet orange peel meal up to $50 \%$ level did not hinder effective digestibility of the feed and nutrient intake of West African Dwarf (WAD) goats. Peels and pulps of oranges contain essential oils (e.g., limonene) that are toxic to

\section{MATERIALS AND METHODS}

The Fungus: The spawn of $P$. pulmonarius and $P$. ostreatus (HK35) were obtained from Zero Emissions Research Institute (ZERI), University of Namibia while $L$. squarrosulus was collected from the Plant Physiology Unit, Botany Department, University of Ibadan, Nigeria. These fungi were multiplied by sub-culturing them through spawn production.

Spawn Multiplication and Preparation: The spawn was prepared according to the method of Adenipekun and Fasidi (2005). This was prepared using Sorghum (Sorghum bicolor) grains as substrate. The sorghum was parboiled to soften it and empty sterile bottles were filled with parboiled sorghum grains and covered with aluminium foil. The bottles were autoclaved at a temperature of $121^{\circ} \mathrm{C}$ for $15 \mathrm{~min}$, allowed to cool and inoculated with spawn. The inoculated grains were incubated at room temperature $\left(28 \pm 2^{\circ} \mathrm{C}\right)$ and allowed to ramify. bacteria and exhibit antioxidant effects in ruminants (Todd et al., 2010). White rot fungi such as Pleurotus ostreatus, Phanerochaete chrysosporium, Lentinus squarrosulus, Lentinus edodes, Coriolus versicolor and Pleurotus florida have been reported to be the most effective lignin degraders which degrade polysaccharides components of agro-wastes and increase digestibility by releasing hydrolytic enzymes from their mycelia (Kuforiji and Fasidi., 2008; Shrivastava et al., 2011). Pleurotus spp. such as $P$. pulmonarius, $P$. ostreatus and $P$. tuber-regium have been reported to possess the potentials of degrading agro wastes into valuable products (Akinfemi et al, 2012; Jonathan et al., 2012; Adenipekun and Aramide, 2015); bio remediate contaminated soils and sites (Adenipekun and Isikhuemhen, 2008 ) and are sources of proteins and medicines (Wani et al., 2013). Lentinus squarrosulus has been reported to possess the potentials of degrading agro wastes, bioremediating and source of proteins and medicines (Adenipekun and Fasidi, 2005; Jonathan et al., 2010; Isikhuemhen et al., 2012). This study is focused on investigating the efficacy of Pleurotus ostreatus (HK35), P. pulmonarius and Lentinus squarrosulus in improving the digestibility and nutritive quality of Citrus sinensis and Musa paradisiaca peels

Substrate Collection and Preparation: The substrates used for this study were Musa paradisiaca $L$. (ripe plantain) peels and Citrus sinensis $L$. (sweet orange peels) collected from Agbowo, Ibadan, Nigeria. The ripe plantain peels were cut into smaller fragments to aid quick drying. The ripe Plantain peels and orange peels were then sundried for 6 weeks and 2 weeks respectively after which, they were milled. Twenty five (25) g of the milled substrates was weighed into jam bottles that had been washed thoroughly and oven-dried for $10 \mathrm{~min}$. at $100^{\circ} \mathrm{C}$ and $70 \mathrm{ml}$ distilled water was added. The bottle was immediately covered with aluminium foil. Fresh weights of the bottles were determined and the bottles were sterilized in the autoclave at $121^{\circ} \mathrm{C}$ for $15 \mathrm{~min}$. The samples were prepared in triplicates (Adenipekun and Fasidi, 2005).

Inoculation of Substrates: The substrate bottles were left to cool and each was inoculated with $5 \mathrm{~g}$ 
of the pure mushroom spawn at the centre and incubated at $28 \pm 2^{\circ} \mathrm{C}$ for 30 and 60 days incubation periods while the control ( 0 days) was left uninoculated. The dry matter of the sample was determined by oven drying at $100^{\circ} \mathrm{C}$ for 48 hours (Bhargava and Orskov, 1987).

Experimental Design and Statistical Analysis: Factorial design of three white-rot fungi, two substrates and three incubation periods was used to set up this experiment. The white rot fungi were $P$. ostreatus (HK35), $P$. pulmonarius, $L$. squarrosulus, the two substrates were: sweet orange peels and ripe plantain peels while the incubation period were 0,30 and 60 days. Data obtained was subjected to analysis of variance ANOVA and the means separated by Duncan's multiple range tests.

\section{Analytical Methods}

1. pH Determination: The $\mathrm{pH}$ of the substrate was measured with a pH metre (H1-8424 microcomputer $\mathrm{pH}$ metre of model $-\mathrm{H} 4382$ ) by adding $100 \mathrm{ml}$ of distilled water to $1 \mathrm{~g}$ of the substrates in the jam bottles. After 18 hours at room temperature, the $\mathrm{pH}$ of each of the treatment was measured (Bates, 2003).

2. Determination of Lignin Content : The lignin content was carried out at Analytical Services Laboratory of the International Institute of Tropical Africa (IITA) according to the method of Southgate (1967) and Van Soest and Wine (2003) described by AOAC (2010). This was determined using the residue from the acid detergent fibre (ADF). Twenty five (25) $\mathrm{ml}$ of combined permanganate solution was added to the residue in a crucible, this was immediately immersed in water bath of $2 \mathrm{~cm}$ depth and a glass rod was used to break the sample into smaller particles. The solution was allowed to stand for 90 minutes at $20^{\circ} \mathrm{C}$ with the purple colour maintained throughout this period and this was later placed under suction for 15 minutes and then filtered. The sample was washed with demineralising agent and subsequently washed twice with $80 \%$ alcohol and followed twice by acetone solution. The sample was oven dried at $105^{\circ} \mathrm{C}$ for 2 hours and the \% lignin was calculated:

\section{$\%$ Lignin $=$ Weight of residue from ADF - Weight of oven dried sample $-\times 100$ Sample weight}

3. Determination of cellulose content: The cellulose content was determined according to the method of Southgate (1967) and Van Soest and Wine (2003) prescribed by AOAC (2010). The cellulose content was determined using the residue from lignin determination. The residue was ashed at $450^{\circ} \mathrm{C}$ for 8 hours, cooled in a desiccator and weighed. The $\%$ cellulose is calculated as follows:

\section{$\%$ Cellulose $=$ Weight of residue from lignin - Weight of ashed sample $\times 100$ Sample weight}

4. Determination of Hemicellulose: The hemicellulose content was determined according to the method of Southgate (1967) and Van Soest and Wine (2003) described by AOAC (2010). The \%

\section{$\%$ Hemicellulose $=\%$ NDF $-\%$ ADF}

5. Determination of In Vitro Digestibility: The in vitro rumen digestibility was determined using neutral detergent procedure by Van Soest and Robertson (1985). Zero point five $(0.5) \mathrm{g}\left(\mathrm{W}_{1}\right)$ of the sample was weighed through a $1 \mathrm{~mm}$ screen into a $125 \mathrm{ml}$ Erlenmeyer flask and $40 \mathrm{ml}$ of the prepared innoculum was added to each flask and incubated for 48 hours in a shaking water bath at $40^{\circ} \mathrm{C}$. The inoculums were prepared by collecting ingesta
Hemicellulose is calculated by subtracting \% NDF (Neutral Detergent Fibre) from \% ADF (Acid Detergent Fibre).

from a fistulated animal in an air tight container, blended in a Wareing blender for 2 mins under $\mathrm{CO}_{2}$ pressure and the blended mass was squeezed through a cloth and filtered through glass wool). After digestion, the flasks were removed from water bath after. The samples were washed with already prepared $50 \mathrm{ml}$ neutral detergent solution into $600 \mathrm{ml}$ Berzelius beaker to make a total volume of $100 \mathrm{ml}$. They were refluxed for 1 hour and 
filtered into crucibles, washed twice with hot water and twice with acetone, and dried using suction. The samples were oven dried at $105^{\circ} \mathrm{C}$ and weighed
$\left(\mathrm{W}_{2}\right)$ and later ashed at $500^{\circ} \mathrm{c}$ and weighed $\left(\mathrm{W}_{3}=\right.$ that is ash + crucible)

Apparent dry matter digestibility $=100-(\mathrm{INDF}-12.9)$

$\mathrm{INDF}=\frac{\left(\mathrm{W}_{2}-\mathrm{W}_{3}\right) \times 100}{\mathrm{~W}_{1} \times \mathrm{DM} \%}$

Where: $\mathrm{W}_{1=}$ weight of sample, $\mathrm{W}_{2}=$ weight of crucible plus fibre, $\mathrm{W}_{3}=$ weight of crucible plus ash, $\mathrm{DM} \%=$ dry matter of original sample, $12.9=$ metabolic constant

6: Determination of organic matter: The organic matter was determined according to the method of AOAC (2010). The samples were ignited at $500^{\circ} \mathrm{C}$ to burn off all organic material. The inorganic

\section{RESULTS}

Table 1 shows the percentage Lignin, Cellulose and Hemicellulose of the treated wastes. There was significant reduction in the lignin level of the peels treated with $P$. ostreatus and $L$. squarrosulus from $65.30 \%$ to $54.80 \%$ and $65.22 \%$ to $61.83 \%$ after 30 days incubation but no significant reduction was observed in the lignin content of peels treated with $P$. pulmonarius at $\mathrm{P} \leq 0.05$. The cellulose level material, which does not volatilise at that temperature is called ash. The difference between sample dry matter DM and ash gives the organic matter.

dropped from $27.42 \%$ to $19.20 \%, 23.80 \%$ to $21.67 \%$ and $28.64 \%$ to $22.02 \%$ for peels treated with L. squarrosulus, $P$. pulmonarius and $P$. ostreatus respectively. Similar trend was observed in the hemicelluloses level of the peels, which decreased from $10.25 \%$ to $9.60 \%, 11.90 \%$ to $10.83 \%$ for $L$. squarrosulus and P. pulmonarius degraded peels respectively after 60days.

Table 1: Effects of Lentinus squarrosulus, Pleurotus ostreatus and Pleurotus pulmonarius treatments on Lignin, Cellulose and Hemicellulose of wastes at various incubation periods.

\begin{tabular}{l|ll|l|l|l}
\hline Fungi & $\begin{array}{l}\text { Incubation period } \\
\text { (Days) }\end{array}$ & Lignin (\%) & Cellulose (\%) & Hemicellulose (\%) \\
\hline L. squarrosulus & 0 & $65.22^{\mathrm{a}}$ & $27.42^{\mathrm{a}}$ & $10.25^{\mathrm{a}}$ \\
& 30 & $61.83^{\mathrm{b}}$ & $25.78^{\mathrm{a}}$ & $8.60^{\mathrm{b}}$ \\
& 60 & $71.20^{\mathrm{a}}$ & $19.20^{\mathrm{b}}$ & $9.60^{\mathrm{ab}}$ \\
P. pulmonarius & 0 & $64.30^{\mathrm{a}}$ & $23.80^{\mathrm{a}}$ & $11.90^{\mathrm{a}}$ \\
& 30 & $68.52^{\mathrm{a}}$ & $20.99^{\mathrm{b}}$ & $10.49^{\mathrm{a}}$ \\
& 60 & $67.50^{\mathrm{a}}$ & $21.67^{\mathrm{b}}$ & $10.83^{\mathrm{a}}$ \\
& & & & \\
& & & & \\
& & $65.30^{\mathrm{a}}$ & $28.64^{\mathrm{a}}$ & $10.17^{\mathrm{a}}$ \\
& 30 & $54.86^{\mathrm{b}}$ & $29.52^{\mathrm{a}}$ & $9.84^{\mathrm{a}}$ \\
& 60 & $66.97^{\mathrm{a}}$ & $22.02^{\mathrm{b}}$ & $11.01^{\mathrm{a}}$ \\
\hline
\end{tabular}

Each value is a mean of 3 replicates. Means with different superscripts in each column are significantly different at $P \leq 0.05$ according to Duncan's multiple range tests

Table 2 shows the $\mathrm{pH}$, Organic matter and Total amino acid contents of the wastes treated with the three mushrooms at different incubation periods. The $\mathrm{pH}$ level increased significantly at $\mathrm{P} \leq 0.05$ from 5.30 to $7.13,5.76$ to 6.86 and 5.49 to 6.33 after 60days incubation for $L$. squarrosulus, $P$. pulmonarius and $P$. ostreatus respectively. A contrary result was obtained for organic matter level, which declined as the incubation period increased from $11.35 \%$ to $7.34 \%, 9.37 \%$ to $7.78 \%$ and $10.71 \%$ to $8.95 \%$ for L. squarrosulus, $P$. pulmonarius and $P$. ostreatus respectively.

Table 2: Effects of Lentinus squarrosulus, Pleurotus ostreatus and Pleurotus pulmonarius treatments on $\mathrm{pH}$ and Organic matter of wastes at various incubation periods. 


\begin{tabular}{l|l|l|l}
\hline Fungi & Incubation Period (Days) & $\mathbf{p H}$ & Organic matter (\%) \\
\hline L. squarrosulus & 0 & $5.30^{\mathrm{b}}$ & $11.36^{\mathrm{a}}$ \\
& 30 & $7.13^{\mathrm{a}}$ & $8.04^{\mathrm{b}}$ \\
& 60 & $6.91^{\mathrm{a}}$ & $7.34^{\mathrm{b}}$ \\
P. pulmonarius & 0 & $5.75^{\mathrm{b}}$ & $9.37^{\mathrm{a}}$ \\
& 30 & $6.68^{\mathrm{a}}$ & $9.18^{\mathrm{a}}$ \\
& 60 & $6.86^{\mathrm{a}}$ & $7.78^{\mathrm{b}}$ \\
P. ostreatus & & & \\
(HK 35) & 0 & $5.49^{\mathrm{b}}$ & $10.71^{\mathrm{a}}$ \\
& 30 & $5.47^{\mathrm{b}}$ & $8.93^{\mathrm{b}}$ \\
\hline & 60 & $6.33^{\mathrm{a}}$ & $8.95^{\mathrm{b}}$ \\
\hline
\end{tabular}

$\overline{\text { Each value is a mean of } 3 \text { replicates. Means with different superscripts in each column are significantly different at }}$ $P \leq 0.05$ according to Duncan's multiple range tests.

Table 3 shows the effects of the treatments on Dry matter content and Digestibility of wastes. As the incubation period increased, the dry matter content also increased significantly at $\mathrm{P} \leq 0.05$ for $L$. squarrosulus $(76.08 \%$ to $87.58 \%)$ and $P$. pulmonarius ( $74.43 \%$ to $85.97 \%$ ) degraded wastes but decreased for peels treated with $P$. ostreatus
( $80.61 \%$ to $78.42 \%)$ after 60 days incubation. The highest digestibility level of $32.49 \%$ was observed for peels treated with $L$. squarrosulus after 30 days while the lowest digestibility level of $19.56 \%$ was observed for peels treated with same fungi after 60 days incubation period.

Table 3: Effects of Lentinus squarrosulus, Pleurotus ostreatus and Pleurotus pulmonarius treatments on Dry Matter and Digestibility of the wastes at various incubation periods.

\begin{tabular}{l|l|l|l}
\hline Fungi & $\begin{array}{l}\text { Incubation period } \\
\text { (Days) }\end{array}$ & $\begin{array}{l}\text { Dry Matter } \\
(\boldsymbol{\%})\end{array}$ & $\begin{array}{l}\text { Digestibility } \\
(\boldsymbol{\%})\end{array}$ \\
\hline L. squarrosulus & 0 & $76.08^{\mathrm{b}}$ & $25.51^{\mathrm{b}}$ \\
& 30 & $80.81^{\mathrm{ab}}$ & $32.49^{\mathrm{a}}$ \\
& 60 & $87.58^{\mathrm{a}}$ & $19.56^{\mathrm{b}}$ \\
P. pulmonarius & 0 & $74.43^{\mathrm{b}}$ & $24.98^{\mathrm{a}}$ \\
& 30 & $83.31^{\mathrm{a}}$ & $24.47^{\mathrm{a}}$ \\
P. ostreatus(HK35) & 60 & $85.97^{\mathrm{a}}$ & $20.75^{\mathrm{a}}$ \\
& 0 & $80.61^{\mathrm{ab}}$ & $22.21^{\mathrm{b}}$ \\
& 30 & $73.63^{\mathrm{ab}}$ & $32.11^{\mathrm{a}}$ \\
\hline
\end{tabular}

Each value is a mean of 3 replicates. Means with different superscripts in each column are significantly different at $P \leq 0.05$ according to Duncan's multiple range tests

Table 4 there was no significant difference in lignin, cellulose and hemicelluloses content of the ripe plantain and sweet orange peels degraded with Lentinus squarrosulus, Pleurotus pulmonarius, and Pleurotus ostreatus (HK35) at $\mathrm{P} \leq 0.05$. The highest and lowest lignin level of $66.98 \%$ was observed in ripe plantain peels treated with $P$. pulmonarius. The lowest hemicellulose $(9.11 \%)$ and cellulose $(22.02 \%)$ contents were observed in plantain peels treated with $L$. squarrosulus and $P$. pulmonarius respectively.

Table 4: Effects of the wastes substrates on the Lignin, Cellulose and Hemicellulose levels of the peels treated with Lentinus squarrosulus, Pleurotus pulmonarius and Pleurotus ostreatus 


\begin{tabular}{l|l|l|l|l}
\hline Fungi & Substrates & Lignin (\%) & $\begin{array}{l}\text { Cellulose } \\
(\%)\end{array}$ & Hemicellulose (\%) \\
\hline L. squarrosulus & Sweet Orange Peels & $65.57^{\mathrm{a}}$ & $24.02^{\mathrm{a}}$ & $9.85^{\mathrm{a}}$ \\
& Ripe Plantain Peels & $66.60^{\mathrm{a}}$ & $24.25^{\mathrm{a}}$ & $9.11^{\mathrm{a}}$ \\
& & & & \\
& & $66.57^{\mathrm{a}}$ & $22.29^{\mathrm{a}}$ & $11.14^{\mathrm{a}}$ \\
& Sweet Orange Peels & $66.98^{\mathrm{a}}$ & $22.02^{\mathrm{a}}$ & $11.01^{\mathrm{a}}$ \\
& Ripe Plantain Peels & & & \\
P.ostreatus & Sweet Orange Peels & $63.83^{\mathrm{a}}$ & $25.84^{\mathrm{a}}$ & $10.23^{\mathrm{a}}$ \\
(HK35) & Ripe Plantain Peels & $60.94^{\mathrm{a}}$ & $27.62^{\mathrm{a}}$ & $10.45^{\mathrm{a}}$ \\
\hline
\end{tabular}

Each value is a mean of 3 replicates. Means with different superscripts in each column are significantly different at $P \leq 0.05$ according to Duncan's multiple range tests.

Table 5 shows the effects of wastes substrates on the, $\mathrm{pH}$ and organic matter of the peels. The $\mathrm{pH}$ of the ripe plantain peels was greater as it ranged from 6.09-6.82 while that of the orange peels was lower as it ranged from 5.43-6.22 with the highest $\mathrm{pH}$ level of 6.82 recorded for ripe plantain peels treated with $P$. pulmonarius. The highest and lowest loss of organic matter of $9.66 \%$ and $8.67 \%$ were obtained from ripe plantain and sweet orange peels treated with $P$. ostreatus and $P$. pulmonarius respectively. Table 6 shows the effects of wastes substrates on digestibility and dry matter content of the peels. The highest digestibility of $26.50 \%$ was obtained from ripe plantain peels treated with $L$. squarrosulus while $23.12 \%$ was the lowest obtained from orange peels degraded with $P$. pulmonarius. The dry matter content of the peels ranged from $75.37 \%$ to $83.09 \%$ with the highest dry matter content of $83.09 \%$ obtained from sweet orange peels treated with $L$. squarrosulus.

Table 5: Effects of the wastes substrates on the $\mathrm{pH}$ and Organic matter of the peels treated with Lentinus squarrosulus, Pleurotus pulmonarius and Pleurotus ostreatus

\begin{tabular}{l|l|l|l}
\hline Fungi & Substrate & pH & Organic matter (\%) \\
\hline L. squarrosulus & Orange Peels & $6.22^{\mathrm{b}}$ & $9.03^{\mathrm{a}}$ \\
& Plantain Peels & $6.73^{\mathrm{a}}$ & $8.79^{\mathrm{a}}$ \\
& & \\
P. pulmonarius & Orange Peels & $6.04^{\mathrm{b}}$ & $8.67^{\mathrm{a}}$ \\
& Plantain Peels & $6.82^{\mathrm{a}}$ & $8.88^{\mathrm{a}}$ \\
P. ostreatus & & \\
(HK35) & Orange Peels & $5.43^{\mathrm{b}}$ & $9.39^{\mathrm{a}}$ \\
\hline
\end{tabular}

Each value is a mean of 3 replicates. Means with different superscripts in each column are significantly different at $P \leq 0.05$ according to Duncan's multiple range tests.

Table 6: Effects of the wastes substrates on Digestibility and Dry matter content of the peels treated with Lentinus squarrosulus, Pleurotus pulmonarius and Pleurotus ostreatus

\begin{tabular}{l|l|l|l}
\hline Fungi & Substrate & Dry Matter (\%) & Digestibility (\%) \\
\hline L. squarrosulus & Sweet Orange Peels & $83.09^{\mathrm{a}}$ & $25.20^{\mathrm{a}}$ \\
& Ripe Plantain Peels & $79.89^{\mathrm{a}}$ & $26.50^{\mathrm{a}}$ \\
P. pulmonarius & Sweet Orange Peels & $80.95^{\mathrm{a}}$ & $23.12^{\mathrm{a}}$ \\
& Ripe Plantain Peels & $81.52^{\mathrm{a}}$ & $23.68^{\mathrm{a}}$ \\
P. ostreatus & Sweet Orange Peels & $75.37^{\mathrm{a}}$ & $26.45^{\mathrm{a}}$ \\
(HK35) & Ripe Plantain Peels & $79.73^{\mathrm{a}}$ & $25.66^{\mathrm{a}}$ \\
\hline
\end{tabular}

Each value is a mean of 3 replicates. Means with different superscripts in each column are significantly different at $P \leq 0.05$ according to Duncan's multiple range tests 


\section{DISCUSSION}

Selective lignin degraders known as white rot fungi have been reported to possess the potentials of improving the digestibility and nutritive quality of agro wastes in a non-toxic manner into value added products such as feed (Kinfemi et al., 2009; Jonathan et al., 2010; Adenipekun and Dada, 2012). The three mushroom species (Pleurotus ostreatus, $P$. pulmonarius and Lentinus squarrosulus) used for this study showed varied potentials in improving the chemical composition and digestibility of the treated peels through the degradation of cell wall components such as hemicelluloses, cellulose and lignin that limits digestion in the rumen of ruminants. These mushrooms are also capable of releasing lignocellullosic enzymes, which degrades call wall components (Jonathan et al., 2010). Result from this study revealed that hemicellulose and cellulose of these peels were degraded most effectively by $L$. squarrosulus while the highest lignin degradation and digestibility was done by P.ostreatus. This is in conformity with the findings of Adenipekun and Fasidi (2005) who reported that wastes degraded by $L$. squarrosulus had higher dry matter, $\mathrm{pH}$ values and lignin degradation when compared to that obtained from $P$. tuber-regium. This is supported by the biodegradation study conducted by Jonathan et al. (2010) using two white rot species and $L$. squarrosulus who reported that the latter degraded the fibre fractions more and improved the crude protein of maize husks better than $P$. tuber regium. However, Bento et al. (2014) findings was contrary to the result obtained, In their study, Pleurotus spp. was found to improve the digestibility and nutritive quality better than the Lentinus spp. used for his work. Variations in the results obtained from these works may be as a result of different mushroom strains and substrates used for the degradation studies. The ability of these fungi to take up products of polysaccharide degradation is demonstrated by the reduction in cellulose, hemicellulose and lignin levels of the treated wastes products when compared with the untreated. In this study, there were significant reductions in hemicellulose, cellulose and lignin contents of the wastes treated with Lentinus squarrosulus, Pleurotus ostreatus and Pleurotus pulmonarius after 30days incubation. This reduction in lignin level was supported by authors like Adenipekun and Fasidi (2005), Jonathan et al.
(2008) and Adenipekun and Aramide (2015) who reported significant reductions in the lignin contents of agro-wastes treated with Pleurotus spp and Lentinus spp. Shriastava et al. (2014); Nasehi et al. (2016) and Atila (2017) also recorded significant decrease in hemicellulose, lignin and cellulose levels of agro wastes products treated with white rot fungi when compared with the control. According to Akinfemi et al. (2010), this decrease in the amount of fibre content of fungaltreated crop residues may be as a result of the degradation of cell-wall components of the substrates by extra cellular enzymes secreted by fungi that lead to increase in the nutritive quality and digestibility of the wastes for animal feeds. Ofuya and Nwanjuiba (1990) stated that the rate at which fungal enzymes are produced during degradation depends on incubation time, $\mathrm{pH}$ and temperature conditions. Thus, the non-significant effects of the treatment on fibre content of the wastes after 60days incubation period may be as a result of inhibition of degradation process of the mushrooms caused by some bacteria, which leads to slow synthesis and release of the enzymes due to changes in conditions of the medium (De Boer et al., 1998). The $\mathrm{pH}$ increased significantly as the incubation period increased. This is in line with the findings of Adenipekun and Dada (2013) who reported an increase in the $\mathrm{pH}$ level of rice straw and cocoa pod degraded by $P$. pulmonarius for 2 months when compared with the control. This change in the $\mathrm{pH}$ may be as a result of increase in amino acid content and metabolic waste products within the substrates (Fasidi, 1996). Hence, these mushrooms were able to improve the $\mathrm{pH}$ value of the wastes close to neutral level making the feeds of better value. This is supported by the findings of Hook et al. (2011) who reported that $\mathrm{pH}$ less than 6.0 or greater than 7 affects the digestibility of the feed in the rumen of ruminants as $\mathrm{pH}$ values lower or higher than the stated values may cause acidosis. Organic matter is the carbon fraction of a sample that is free from water and inorganic substances. The values of organic matter of the treated peels are lower than that of the untreated. This result obtained from this study is line with the findings of Fazaeli et al. (2006) and Rahman et al. (2011.) who recorded decrease in organic matter content of fungal-treated crop residues. Also, the values of organic matter lost obtained from this study is 
lower when compared to $53.40 \%$ to $76.60 \%$ obtained from banana wastes degraded by Oyster mushrooms (De Carvalho et al., 2012). Organic Matter Loss may occur due to $\mathrm{CO}_{2}$ and $\mathrm{H}_{2} \mathrm{O}$ lost during metabolic activities of microorganisms and not only from the removal of materials from basidiomata construction (Zadrazil, 1978). Results obtained from the in vitro digestibility of these peels showed that the digestibility of the peels increased after 30 days incubation period when compared with the control. This suggests that these mushrooms possess the ability of improving the digestibility of peels for easy digestion in the rumen of ruminants. Hence, the treated wastes could be incorporated into the ration of ruminant's feeds. The result obtained from this work is in accordance with the findings of Bento et al. (2014) who reported similar results for agro- wastes treated with Pleurotus sp. and Lentinus sp. This increase in the digestibility of the treated wastes

\section{CONCLUSION}

The three mushrooms displayed varying degrading potentials as they were able to alter the physicochemical properties of these substrates peels to make them easily digestible in the rumen of animals. There was significant degradation of lignin and cellulose and hemicelluloses contents of these wastes treated with Pleurotus ostreatus and Lentinus squarrosulus respectively. The highest digestibility level was recorded in peels treated

\section{REFERENCES}

Adenipekun CO. and Fasidi IO. 2005. Degradation of selected agricultural wastes by Pleurotus ostreatus (Fries) Singer and Lentinus subnudus (Berk) Nigeria edible mushrooms. Advanced Food Science. 27:61-64.

Adenipekun CO and Isikhuemhen OS. 2008. Bioremediation of engine oil polluted soil by the tropical white rot fungus, Lentinus squarrosulus Mont. (Singer). Bioremediation of engine oil polluted soil by the tropical white rot fungus, Lentinus squarrosulus Mont. (Singer). Pakistan Journal of Biological Sciences 11(12): 1634-1637.

Adenipekun CO, Okunlade OA. and Ogunjobi AA. 2012. Effect of Pleurotus tuber-regium Singer on degradation of rattan wood and may be due to reduction in the lignin level, as high level have been reported to limit the digestibility of agro-wastes (Jonathan et al., 2010; Akinfemi et al., 2012). The differences in the rate of improvement of digestibility of these peels by the different mushrooms used for this study may be as a result of variation in the chemical composition of the peels and the enzyme activities of the fungi. Determination of dry matter content is important because it increases the shelf life and reduces the risk of bacterial contamination and also prepares the samples for various analytical tests (Van Loon et al., 2000). Increase in dry matter content of the degraded wastes was recorded as the incubation period increased. This corresponds with the findings of Adenipekun and Aramide (2013) who obtained similar result. This increase may be as a result of the breakdown of the cell wall bonds of the wastes during the degradation process by the fungi (Fazaeli et al., 2004).

with $P$. ostreatus and Plantain treated peels were the most nutritive improved when compared to that of orange. 30 days incubation period was observed to be the most suitable incubation period for improving the digestibility and nutritive quality of the peels. Hence, these could be incorporated into the diet of ruminant. However, the efficacy of these peels as alternative sources of feed could be tested on live animals.

maize stovers. Journal of Applied Biosciences 51:3633-3641.

Adenipekun CO. and Dada OJ. 2013. Biodegradation of Three Agricultural Wastes by white-rot fungus Pleurotus pulmonarius (Fries) Quetlet. Nature and Science 11(2): 19-25.

Adenipekun CO. and Aramide FA. 2015. Influence of wheat bran on degradation of agricultural wastes by white rot fungus, Lentinus squarrosulus (Mont.) Singer. Nigeria Journal of Ecology 14:13-20.

Akinfemi A, Adu OA, Doherty F. 2010. Conversion of sorghum stover into animal feed with white-rot fungi: Pleurotus ostreatus and Pleurotus pulmonarius. African Journal of Biotechnology 9:17061712 
Akinsanmi AO, Oboh G, Akinyemi J, Ayodele, Adefegha AS. 2015. Assessment of the Nutritional, Anti nutritional and Antioxidant capacity of Unripe, ripe, and over ripe Plantain (Musa paradisiaca) Peels. International Journal of Advanced Research 3(2):63-72.

Akinyele BJ. and Agbro O. 2007. Increasing the nutritional value of plantain wastes by the activities of fungi using the solid state fermentation technique. Research Journal of Microbiology 2(2):117-124.

AOAC. 2010. Official methods of analysis of the association of official's analytical chemists, 17th edn. Association of official analytical chemists, Arlington, Virginia.

Atila F. 2017. Biodegradation of different agroindustrial wastes through the cultivation of Pleurotus ostreatus (Jacq. ex. Fr) Kumm. Journal of Biological and Environmental Science 11(31):1-9.

Babayemi OJ, Demeyer D, Fievez, V. 2004. Nutritive value and qualitative assessment of secondary compounds in seeds of eight tropical browse, shrub and pulse legumes. Communications in Agriculture and Applied Biological Science 69: 103-110.

Bates RG. 2003. Determination of pH, Theory and practice ( $2^{\text {nd }}$ Edition), New York 77-79.

Bento PC, da Silva, JS, Rodrigues M, Kasuya MC, Mantovani HC. 2014. Influence of white rot fungi on chemical composition and in vitro digestibility of lignocellulosic agroindustrial residues. African Journal of Microbiology Research 8(28):2724-2732.

Bhargava RK. and Orskov ER. 1987. Manual for the use of Nylon bag technique in the evalauation of feed stuff pp21.

De Boer, W, Klein-Gunnewiek, PJ, Lafeber, P, Janse, JD, Spit, BE, Woldendorp, JW 1998. Antifungal properties of chitinolytic dune soil bacteria. Soil Biology and Biochemistry 30:193-203.

De Carvalho, CS, de Aguiar, LV, Sales-Campos, C, de Almeida Minhoni, MT, de Andrade, MCN. 2012. Applicability of the use of waste from different banana cultivars for the cultivation of the oyster mushroom. Brazilian Journal of Microbiology 43(2):819-826.
FAO. 2013. FAOSTAT. Food and Agriculture Organization of United Nations, Rome. Rome. http://faostatfao.org

Fasidi IO. 1996. Studies on Volvariella esculenta: Cultivation on agricultural wastes and proximate composition of stored mushrooms. Food Chemistry 55:165-168.

Fazaeli H, Mahmodzadeh H, Jelan ZA, Rouzbenhan Y, Liang JB, Azizi, A. 2004. Utilization of fungal treated wheat straw in the diet of late lactating cow. AsianAustraian Journal of Animal Science 17:467-472.

Fazaeli H, Azizi, A, Amile M. 2006. Nutritive value index of treated wheat straw with Pleurotus fungi fed to sheep. Pakistan Journal of Biological Sciences 9:24442449.

Hook SE, Steele MA, Northwood KS, Wright AD, McBride BW. 2011. Impact of highconcentrate feeding and low ruminal $\mathrm{pH}$ on methanogens and protozoa in the rumen of dairy cows. Journal of Microbial Ecology 62(1):94-105.

Isikhuemhen OS, Mikiashvili NA, Adenipekun CO, Ohimain EI, Shahbazi G. 2012. The tropical white rot fungus, Lentinus squarrosulus Mont.: lignocellulolytic enzymes activities and sugar release from cornstalks under solid state fermentation. World Journal of Microbiology and Biotechnology 28(5): 1961-1966.

Jonathan SG, Okorie AN, Garuba EO, Babayemi OJ. 2012. Bioconversion of sorghum stalk and rice straw into value added ruminant feed using Pleurotus pulmonarius. Nature and Science 10(4):10-16.

Jonathan SG, Akinfemi A, Adenipekun CO. 2010. Biodegradation and In vitro digestibility of maize husks treated with edible fungi (Pleurotus tuber-regium and Lentinus subnudus from Nigeria. Electronic Journal of Environmental, Agricultural and Food Chemistry 9(4):742-750.

Jonathan SG, Fasidi IO, Ajayi A.O, Adegeye A. 2008. Biodegradation of Nigerian wood wastes by Pleurotus tuber-regium (Fries) Singer. Bioresource Technology 99:807811.

Kinfemi AA, Mohamed MI, Ayoade JA. 2009. Biodegradation of Cowpea Shells by 
Pleurotus species for its use as Ruminant Feed. World Journal of Agricultural Sciences 5(5):639-645

Kuforiji OO and Fasidi IO. 2008. Enzyme activities of Pleurotus tuber-regium (Fries) Singer, cultivated on selected agricultural wastes. Bioresource Technology 99(10):4275-4278.

Nasehi M, Torbatinejad, NM., Zerehdaran S, Safaie AR. 2016. Effect of solid-state fermentation by oyster mushroom (Pleurotus florida) on nutritive value of some agro by-products. Journal of Applied Animal Research 45(1):221-226.

Ofuya CO and Nwanjuiba CJ. 1990. Microbial degradation and utilization of cassava peel. World Journal of Microbiology and Biotechnology 6:144-148.

Oloche J, Ayoade JA, Oluremi OI. 2013. Effect of replacement of sweet orange (Citrus Sinensis) peel meal with maize offal on apparent digestibility and nutrient intake of West African Dwarf (Wad) goats. Journal of Agriculture and Veterinary Science 5:01-04.

Pala SA, Wani A, Boda RH, Wani BA 2014. Mushroom refinement endeavor auspicate non green revolution in the offing. Nusantara Bioscience 6 (2): 173-185.

Rahman MM, Lourenco M, Hassim HA, Baars JP, Sonnenberg AS, Cone JW, DeBoever, J, Fievez V. 2011. Improving ruminal degradability of oil palm fronds using white rot fungi. Journal of Animal Feed Science and Technology 169:157-166.

Shrivastava B, Thakur S, Khasa YP, Gupte A, Puniya, AK, Kuhad RC. 2011. White rot fungal conversion of wheat straw to energy rich cattle feed. Journal of Biodegradation 22:823-831

Todd C, Tom E, Steven R, Phil C. 2010. Project summary: Orange Pulp and Peel as Feedstuffs to Reduce E. coli O157:H7 and Salmonella Populations in Ruminants National Cattlemen's Beef Association, 9110 East Nichols Avenue Centennial, Colorado 80112-3450(303) 694-0305

Van Loon PC, Swinkels HA, vanGriensven LJ. 2000. Dry matter content in mushrooms (Agaricus bisporus) as an indicator for mushroom quality. In: Science and
Cultivation of Edible Fungi, Van Griensven (ed.), Balkema, and Rotterdam: 507-513.

Van Soest PJ and Robertson JB. 1985. Analysis of Forages and Fibrous Foods. A Laboratory Manual for Animal Science .Cornell University, Ithaca, New York, USA pp 613.

Van Soest PJ and Wine RJ. 2003. Determination of Lignin and Cellulose in Acid Detergent Fibre with Permanganate. Journal of the Association of Official Agricultural Chemists 51:780-785.

Wanderley RC. Silva A.G, Manzano A, Bulau R, Mendes, R.L, Zagatto, LCAG, Novaes NJ. 1994. Niveis de silagem de bagaco de citrus na engorda de bovinos. Anais Reun. Anual da Sot. Bras. Zoot., Maringa 692.

Wani BA, Bodha RH, Wani, AH. 2010. Nutritional and medicinal importance of mushrooms. Journal of Medicinal Plants Research 4(24): 2598-2604.

Zadrazil F. 1978. Cultivation of Pleurotus. In: Ghang S.T, Hayes W.A, editors. The Biology and Cultivation of Edible Mushrooms. Nova Yorque: Academic Press EEUU pp. 521-557. 